\title{
An Analysis on Influence of Sea Water Salinity and Acidity in Jakarta Ports Towards Corrosion Rate of Steel Plate as Ship Material
}

\author{
Diah Zakiah', Yuni Mariah ${ }^{2}$, Deny Fitrial $^{3}$, Asman $\mathrm{Ala}^{4}$ \\ \{ asdia73@gmail.com ${ }^{1}$, yunimariah71@gmail.com ${ }^{2}$,dnyfr1@gmail.com ${ }^{3}$, \\ asmala_ftuhftui@yahoo.com ${ }^{4}$ \} \\ ${ }^{1,2,3,4}$ STIP (Sekolah Tinggi Ilmu Pelayaran) Jakarta, Indonesia
}

\begin{abstract}
Corrossion of the ship, caused by sea water, is still a big problem since the ship body material is mostly based on iron and steel. This material is proven tough and strong but susceptible to corrosion. Corrosion causes gradual destruction of ship materials, inhibits ship manouvre, and shortens the usage time of ship. Acidity and salinity of seawater as the main factor of corrosion will be made as a parameter in this research to analyze how much these factors affect corrosion rate
\end{abstract}

Keywords: corrosion, salinity, acidity, sea water, steel

\section{Introduction}

One of the biggest factors of damage to ships is caused by seawater corrosion. Until now the use of iron and steel as the main material for shipbuilding is still dominant. In terms of cost and strength, the use of iron and steel for shipbuilding is quite adequate. In the other hand steel is very reactive and has a large tendency to be attacked by seawater corrosion. Corrosion is a degradation process from a metal element due to the chemical reaction between the metal and its environment. Basically corrosion is the event of the release of electrons from metal (iron or steel) which is in an electrolyte solution such as seawater. Whereas positively charged atoms of metal $(\mathrm{Fe}+3)$ will react with hydroxyl $(\mathrm{OH}-)$ ions to form ferric hydroxide $[\mathrm{Fe}(\mathrm{OH}) 3]$ which is known as rust. Based on the terms of construction on a ship, the lambadiral plate is the area that was first exposed to seawater. In this hull area the underwater or the upper water area is exposed to corrosion. Corrosion on the ship's body plate can cause a decrease in the strength and age of the ship's use, reduce the speed of the ship and reduce the guarantee of safety and security of cargo and passenger-cargo.

Steel has long been widely used in the shipping industry as the main plate component in the body and hull of the ship. In the shipping industry environment, the use of steel materials ranks first as a component of shipbuilding, main engines, and ship assisting machines. On one side the steel material inside the ship is very susceptible to corrosion attacks which can reduce the quality of the ship's material. The impact of the threat of corrosion on ships with steel material can also worsen their appearance and shorten the useful life of the steel vessel.

The sea is the most extensive area on the world, with $70 \%$ of the entire surface of the world and has the ability to corrode metals quickly because it consists of a variety of material content (salts, solutes, organic materials, and non-soluble particles. Electrolyte sea water tends to be acidic and containing salt is a good medium for carrying out charge transfers which will accelerate the electrochemical process that can cause corrosion. 
The degree of acidity or $\mathrm{pH}$ is the number of $\mathrm{H}+$ ions found in aquatic systems or commonly known as acidity. Seawater generally has a low $\mathrm{pH}$ (tends to acid) which causes rapid corrosion in the open part of the ship's hull due to scratched ship hulls. The corrosion rate in acidic conditions with $\mathrm{pH}<7$ is greater because of the additional reduction reaction that takes place at the cathode causing more metal atoms to be oxidized so that the corrosion rate on the metal surface increase.

Salinity is the level of salt dissolved in water. Seawater contains chloride salts and other salts with salinity levels ranging from $3-4 \%$. The presence of electrolytes such as salt in seawater can accelerate the corrosion rate by increasing the occurrence of additional reactions. Large electrolyte concentrations can increase the electron flow rate so that the corrosion rate increases.

Electrolyte-containing seawater containing salts and tends to be acidic can accelerate the corrosion rate. The level of acidity and salinity of various seawater causes the corrosion rate of the steel material of the vessel to also vary.

seawater factors affect the corrosion of the ship's material, for example, Salinity, Acidity $(\mathrm{pH})$, temperature, and Dissolved substances and particles. In this study, we limit the factors only in the amount of salinity and acidity $(\mathrm{pH})$.

Here we also want to identify seawater with the highest corrosion rate in relation with the influence of the acidity and salinity of seawater, so we get sea water sample from three ports in Jakarta, Tanjung Priuk, Muara Angke, Sunda Kelapa

\section{Literature Review}

\subsection{The basic theory of corrosion}

NACE (National Association of Corrosion Engineers) defines corrosion as a decrease in the quality of material (usual steel) or its properties caused by a reaction with its environment [1]; Mulbyantoro [2]. Whereas Trethewey [3] provides a definition of corrosion as a decrease in the quality of steel due to electrochemical reactions to the environment [1]. Furthermore ASM Materials Engineering Dictionary states corrosion as a chemical or electrochemical reaction between steel anodes and cathodes with an electrolyte environment which results in a decrease in material quality and chemical properties.

Basically all steel is unstable and tends to react with its environment, forming a stable oxide or carbonate compounds. The tendency of steel to release electrons during an electrochemical reaction process in forming corrosion shows the active nature of the steel in question.

Corrosion is a reaction between metals and their environment. Things that affect the rate of corrosion are for example temperature, oxygen content, solution concentration, $\mathrm{pH}$, the difference in aeration and several other influences. In general, the increase in the value of the factors that cause corrosion will also increase the corrosion rate of the metal. Electrochemical corrosion can be illustrated by the reaction between metal ions and water molecules. At first there will be hydrolysis which causes acidity to increase. This can be explained by the following equation.

$$
\mathrm{M}++\mathrm{H} 2 \mathrm{O} \rightarrow \mathrm{MOH}+\mathrm{H}+
$$

This equation illustrates the general hydrolysis reaction, where in actual electrolytes there will be an important role for chlorides but will be complicated to decipher. Chloride has a low tendency to join hydrogen ions in water. This encourages a decrease in the $\mathrm{pH}$ of the electrolyte solution. The reaction equation if the reaction above is a reaction between iron ions and water molecules is as follows: 
$\mathrm{Fe}++\mathrm{H} 2 \mathrm{O}-\rightarrow \mathrm{Fe}(\mathrm{OH})++\mathrm{H}+$ Iron (II) Iron (II)

Then this reaction can continue with the oxidation reaction by the presence of oxygen to iron (II), so that iron (III) ions will form. The reaction equation can be described as follows:

$\mathrm{Fe}(\mathrm{OH})++1 / 2 \mathrm{O} 2+2 \mathrm{H}+2 \mathrm{Fe}(\mathrm{OH}) 2++\mathrm{H} 2 \mathrm{O}$

Subsequent reactions are possible, which cause the solution to become more acidic.

$\mathrm{Fe}(\mathrm{OH}) 2++\mathrm{H} 2 \mathrm{O}+2 \mathrm{Fe}(\mathrm{OH}) 2++\mathrm{H}+$

Henceforth, it can be described the reaction of complex ionic elements to form the main corrosion results, namely magnetite and rust, respectively expressed by $\mathrm{FE} 3 \mathrm{O} 4$ and $\mathrm{FeO}(\mathrm{OH})$

Corrosion of the ship's steel material

Seawater that has electrolyte properties tends to be acidic and contains salt which is a good medium for carrying out charge transfers which will accelerate the electrochemical process that can cause corrosion.

The degree of acidity or $\mathrm{pH}$ is the number of $\mathrm{H}+$ ions found in a water system or commonly known as acidity[4]. Seawater generally has a low $\mathrm{pH}$ (tends to be acidic) which causes rapid corrosion in the open part of the ship's hull due to scratched ship hull paint. Corrosion rates in acidic conditions with $\mathrm{pH}<7$ are greater because of the additional reduction reactions that take place at the cathode causing more metal atoms to be oxidized so that the corrosion rate on the metal surface gets bigger.

Salinity is the level of salinity or the level of salt that dissolved in water. Seawater contains chloride salts and other salts with salinity levels ranging from 3 - 4\%. The presence of electrolytes such as salt in seawater can accelerate the corrosion rate by adding additional reactions. Large electrolyte concentrations can increase electron flow rates so that the corrosion rate increases[5].

Electrolyte seawater which containing salts and tends to be acidic can accelerate the corrosion rate. The varying levels of acidity and salinity of seawater cause the corrosion rate of the steel material in the vessel to also vary.

Steel has long been widely used in the shipping industry as the main plate component in the body and hull of the ship. In the shipping industry environment, the use of steel materials ranks first as a component of shipbuilding, main engines, and ship assisting machines. But on the other hand, the steel material inside the ship is very susceptible to corrosion attacks which can reduce the quality of the ship's material. The impact of the threat of corrosion on ships with steel material can also worsen their appearance and shorten the lifespan of these steel vessels.

\subsection{Research Objectives}

To analyze the effect of salinity and acidity $(\mathrm{pH})$ on the corrosion rate of steel as a vessel material. To find out the sea water which causes a high corrosion rate, it can be seen from the influence of acidity and salinity.

\subsection{Research Places And Times}

The place of research was conducted at the Jakarta Chemical Laboratory. The time of research starts from October to November 2017. 


\section{Method}

\subsection{Test Material}

Specimens (test specimens) for this research process were selected ST-40 steel plates which have properties similar to the plates for ships.

The seawater solution used was made in a chemical laboratory with salinity and seawater samples from the ports of tj priuk, muara angke and sunda kelapa.

\subsection{Testing The Degree Of Acid And Salinity}

To test the acidity of the seawater test solution, a pH meter was used and to test salinity a refractometer was used.

\subsection{Testing Of Corrosion (Immersion Test)}

Immersion Test for specimens of steel plate specimens of ship material. This method is commonly used to determine the resistance of the material (coating) to conditions similar to the actual environment, namely resistance to acidic solutions and salts. The solution used in this test is seawater with salinity $3.3 \%, 3.5 \%$ and $3.8 \%$ with a $\mathrm{pH}$ of 6.5 and 4 respectively.

Before this test, the specimen was weighed first to determine the initial weight before testing. This specimen is weighed using the OHAUS brand Electronic Analytical Balance weigher, room temperature and humidity. This selection is based solely on economic considerations. By calculating the average area of specimens immersed, it can be seen the volume of seawater needed to soak the specimen. Duration of testing for 1 week.

\subsection{Calculating Corrosion Rate}

Corrosion rates can be determined using the following equation:

$$
\text { 534. W }
$$

$\mathrm{MPY}=$

$$
\text { D. A. T }
$$

$\mathrm{Mm} / \mathrm{yr}=\frac{\text { 87.6. } \mathrm{W}}{\text { D. A. } \mathrm{T}}$

Where:

$\mathrm{W}=$ mass lost due to corrosion, milligrams $(\mathrm{mg})$

$\mathrm{D}=$ mass meeting, gram per cubic centimeter $(\mathrm{gr} / \mathrm{cm} 3) ; 7,8 \mathrm{mgr} / \mathrm{m} 3$ or $490 \mathrm{lb} / \mathrm{ft} 3$

$\mathrm{A}=$ surface area, square inches (in2); $\mathrm{T}=$ duration of testing (hours).

\subsection{Research And Statistical Analysis Variables}

The attributes in this study are independent variables (latent variables) are the degree of acidity and salinity. And as a dependent variable (construct variable) is the rate of corrosion of the steel plate of a ship's material. The data analysis used is correlation and regression. 
Statistical regression analysis is the study of dependent variable dependence on one or more independent variables, with the aim of estimating and or predicting population averages or the average value of the dependent variable based on the value of the known independent variable, Imam Ghazali ( 2001). The focus is on explaining and evaluating the relationship between a variable with one or more independent variables.

In this study, the regression equation is:

$$
\begin{aligned}
& \dot{Y}=\mathrm{a}+\mathrm{b} 1 \mathrm{X} 1+\mathrm{b} 2 \mathrm{X} 2 \\
& \text { Information : }
\end{aligned}
$$

$\mathrm{Y}=$ Variable is not free (Corrosion Rate)

$\mathrm{X} 1=$ Independent variable (Salinity)

$\mathrm{X} 2=$ Free variable (Acidity degree)

$\mathrm{a}=$ price $\mathrm{Y}$ if $\mathrm{X} 1$ and $\mathrm{X} 2=0$ (constant price)

$\mathrm{b} 1$ = Salinity variable regression coefficient, the value of the comparison value of the $\mathrm{Y}$ estimate if $\mathrm{X} 1$ changes 1 unit and $\mathrm{X} 2$ is constant.

$\mathrm{b} 2$ = variable regression coefficient Acidity degree, the magnitude of the comparative value of the value of $\mathrm{Y}$ estimator if $\mathrm{X} 2$ changes 1 unit and $\mathrm{X} 1$ is constant.

\subsection{Hypothesis testing}

That is to test the significance of the regression model or assess the goodness of Fit. This can at least be measured from the coefficient of determination, the value of the F statistic or the statistical value $t$. Statistical calculations are called statistically significant if the statistical test value is in a critical area (the area where $\mathrm{H} 0$ is rejected). On the contrary, it is called insignificant if the statistical test value is in the area where $\mathrm{H} 0$ is accepted.

\subsection{Coefficient of Determination}

The coefficient of determination (R2) essentially measures how far the model's ability to explain the variation of the dependent variable. The coefficient of determination is between zero and one. The small value of R2 means that the ability of independent variables to explain variations in the dependent variable is very limited. A value close to one means that the independent variables provide almost all the information needed to predict variations in the dependent variable.

\subsection{Individual Parameter Significance Test (Test Statistic t)}

The t-test statistic shows how far the influence of one explanatory variable / independent individually in explaining the variation of the dependent variable. The null hypothesis (H0) to be tested is whether a parameter (bi) equals zero, or:

H0: $b i=0$

That is, whether an independent variable is not a significant explanation for the dependent variable. The alternative hypothesis $(\mathrm{Ha})$ the parameter of a variable is not equal to zero, or:

Ha: bi $\neq 0$

That is, the variable is a significant explanation of the dependent variable. One way to do the t-test is to compare the value of the $t$ statistic with the critical point according to the table. If the t-statistic value of the calculation results is higher than the value of the table, it means accepting the alternative hypothesis which states that an independent variable individually affects the dependent variable. The significance of the relationship between variables can also 
be seen from the probability value (p-value). If the p-value is $<0.05$, the null hypothesis is rejected and accepts the alternative hypothesis. Conversely, if p-value> 0.05 means that the null hypothesis is accepted and reject the alternative hypothesis.

\section{Result and Discussion}

\subsection{Description of Data}

a. Tanjung Priok Port

Nth sampel test Salinity (0/00) $\quad \mathrm{pH} \quad$ Corrosion Rate (mm/year)

$\begin{array}{llll}1 & 3,4 \% & 6,3 & 0,501\end{array}$

$2 \quad 3,5 \% \quad 6,4 \quad 0,498$

$3 \quad 3,5 \% \quad 6,4 \quad 0,491$

$4 \quad 3,4 \% \quad 6,5 \quad 0,452$

$5 \quad 3,3 \% \quad 6,7 \quad 0,447$

$\begin{array}{llll}6 & 3,5 \% & 6,4 & 0,489\end{array}$

$7 \quad 3,4 \% \quad 6,5 \quad 0,452$

$\begin{array}{llll}8 & 3,5 \% & 6,4 & 0,497\end{array}$

$9 \quad 3,5 \% \quad 6,4 \quad 0,497$

$\begin{array}{llll}10 & 3,6 \% & 6,2 & 0,512\end{array}$

Soures: Result Test Lab (2017)

Table 1Lab 1 test results data

b. MuaraAngke Port

Nth sample test

$\begin{array}{lll}1 & 3,5 \% & 6,4\end{array}$

Salinity $(0 / 00) \quad \mathrm{pH} \quad$ Corrosion Rate (mm/year)

$\begin{array}{lll}2 & 3,5 \% & 6,4\end{array}$

0,449

0,448

0,435

$4 \quad 3,7 \% \quad 6,3 \quad 0,457$

$\begin{array}{llll}5 & 3,6 \% & 6,2 & 0,501\end{array}$

$\begin{array}{llll}6 & 3,6 \% & 6,2 & 0,512\end{array}$

$7 \quad 3,7 \% \quad 6,4 \quad 0,448$

$8 \quad 3,8 \% \quad 6,1 \quad 0,621$

$9 \quad 3,7 \% \quad 6,4 \quad 0,447$

$\begin{array}{llll}10 & 3,8 \% & 6,2 & 0,514\end{array}$

Table 2Table 2. Lab 2 test results data

c. SundaKelapa Port

\section{Nth sample test}

$13,4 \% \quad 6,5$

$2 \quad 3,3 \% \quad 6,7$

$3 \quad 3,3 \% \quad 6,7$

$4 \quad 3,4 \% \quad 6,5$

$5 \quad 3,4 \% \quad 6,5$

$6 \quad 3,6 \% \quad 6,2$

$\begin{array}{lll}7 & 3,5 \% & 6,4\end{array}$

$8 \quad 3,5 \%$

$93,6 \%$

$10 \quad 3,4 \%$
Salinity (0/00) $\quad \mathrm{pH} \quad$ Corrosion Rate (mm/year)

0,491

0,374

0,385

0,492

0,475

0,605

0,522

0,501

$6,3 \quad 0,545$

$6,5 \quad 0,475$ 
Table 3 Lab 3 test results data

Based on the graph, the three locations of Tanjung Priok, MuaraAngke and SundaKelapa ports showed that the corrosion rate was linearly affected by the salinity level and $\mathrm{pH}$ value of seawater. Of the three locations, it appears that there is no sharp difference except for the port of MuaraAngke, where the corrosion rate is slightly high due to the acidity of the seawater.

\subsection{Statistical Analysis}

From the test results using a statistical analysis tool on the effect of acidity and $\mathrm{pH}$ on the Corrosion Rate of the Ship Material Steel Plate in 3 (three) North Jakarta ports, the results are summarized as follows:

Variable *) CoeffisientRegression Coefficient Beta t count P-value

Salinity $\quad 0,384 \quad 0,496 \quad 3,994 \quad 0,001$

Acidity (pH) $-0,515 \quad-0,534 \quad-5,128 \quad 0,001$

*) DependentVariable :CorrosionRate

Table 4Effect of Salinity and Acidity $(\mathrm{pH})$ on the Corrosion Rate of Ship Material Steel Plate (Tanjung Priok Port)

Source: the result of data processing (Appendix 1)

Based on Table 4 above shows that the magnitude of the effect of Salinity on Corrosion Rate in Tanjung Priok Port can be seen in the Beta Coefficient which is equal to 0.496 or $49.6 \%$, this is evidenced from the statistical value of $\mathrm{t}$ count $3.994>\mathrm{t}$ table 1,812 ( $\mathrm{n}=10, \square=$ $5 \%$, one-tailed) with a measurement error rate that is low below $5 \%$ (p-value 0.001$)$. The regression coefficient means that if the salinity number rises by 1 unit then this will increase the corrosion rate measured by 0.384 .

Similarly the degree of acidity $(\mathrm{pH})$ with a Beta Coefficient of -0.534 or $53.4 \%$. The minus sign here means there is a negative relationship between the $\mathrm{pH}$ value and the corrosion rate. The lower the $\mathrm{pH}$ value the more the corrosion rate rises. The significance of the effect of $\mathrm{pH}$ acidity is evidenced by the statistic value of $t-5.128>1.812$ with a low level of measurement error ( $\mathrm{p}$-value 0.001 . The regression coefficient means that if the $\mathrm{pH}$ number drops by 1 then this will increase the corrosion rate measured by 0,515 .

\section{a. Statistic Test 2}

Variabel *) CoeffisientRegression Coeffisien Beta t count P-value

Salinity $\quad 0,203 \quad 0,657 \quad 3,030 \quad 0,000$

Acidity (pH) $\quad-0,398 \quad-0,872 \quad-4,032 \quad 0,000$

*) DependentVariable :CorrosionRate

Table 5Effect of Salinity and Acidity $(\mathrm{pH})$ on the Corrosion Rate of Ship Material Steel Plate (MuaraAngke Port)

Source: the result of data processing (Appendix 2)

Based on Table 5 above shows that the magnitude of the effect of Salinity on Corrosion Rate in MuaraAngke Port can be seen in the Beta Coefficient which is equal to 0.657 or $65.7 \%$, this is evidenced by the statistical value $\mathrm{t}$ count $3.030>\mathrm{t}$ table 1,812 ( $\mathrm{n}=10, \square=5 \%$, onetailed) with a low level of measurement error (p-value 0,000). The regression coefficient means that if the salinity number rises by 1 unit then this will increase the corrosion rate measured by 0.203 . 
Similarly, the acidity $(\mathrm{pH})$ with the Beta Coefficient -0.872 or $87.2 \%$ corrosion rate is influenced by the $\mathrm{pH}$ value. The minus sign here means there is a negative relationship between the $\mathrm{pH}$ value and the corrosion rate. The lower the $\mathrm{pH}$ value the more the corrosion rate rises. The significance of the effect of $\mathrm{pH}$ acidity is evidenced by the statistical value $\mathrm{t}$ 4.032> t table 1.812 with a very low level of measurement error ( $\mathrm{p}$-value 0.000 ). The regression coefficient means that if the $\mathrm{pH}$ number drops by 1 unit then this will increase the measured corrosion rate by $-0,398$.

b. Statistic Test 3

\begin{tabular}{llllll} 
Variabel *) & \multicolumn{2}{l}{ CoeffisientRegression } & Coeffisient Beta & tcount & P-value \\
Salinity & 0,379 & 0,595 & 3,805 & 0,002 & \\
Acidiy $(\mathrm{pH})$ & $-0,684$ & $-0,665$ & $-4,375$ & 0,000 & \\
*) DependentVariable :CorrosionRate & &
\end{tabular}

Table 6. Effect of Salinity and Acidity $(\mathrm{pH})$ on the Corrosion Rate of Ship Material Steel Plate (SundaKelapa Port)

Source: the result of data processing (Appendix 3)

Based on table 6 above shows that the magnitude of the influence of Salinity against Corrosion Rate in Sunda Kelapa Port can be seen on a Beta coefficient i.e. of 0.595 or $59.5 \%$, this is supported by data value $\mathrm{t}$ calculate statistics $3.805>\mathrm{t}$ table $1.812(\mathrm{n}=10, \square=5 \%$, onetailed) with a low level of measurement error of $5 \%$ limit (p-value 0.001 ). The regression coefficient of 0.379 recalls that when the figure rises by 1 unit then the salinity will increase the rate of corrosion is measured of 0.379 .

Similarly, the degree of acidity $(\mathrm{pH})$ and Beta coefficient- 0.665 or $66.5 \%$ the rate of corrosion is affected by the $\mathrm{pH}$ value. The minus sign indicates a negative relationship exists between a $\mathrm{pH}$ value with the rate of corrosion. The lower the $\mathrm{pH}$ value is then the rate of corrosion is getting up. The significance of the influence of the degree of acidity the $\mathrm{pH}$ it is reinforced as well as from the statistical value $\mathrm{t}$ calculate-4.375 $>\mathrm{t}$ table 1.812 with low measurement error level (p-value of 0.000 ). While the regression coefficient values, his numbers indicate when 0.684 .

Based on the results of testing the influence of salinity and the degree of acidity $(\mathrm{pH})$ against corrosion rate on steel plate material existing ships in 3 (three) the location of the port of Tanjung Priok Harbor, MuaraAngke and the port of Sunda Kelapa, then gave an overview the influence of salinity and the degree of acidity of the greatest happening is in the port of MuaraAngke, followed by the port of Sunda Kelapa and lowest in Tanjung Priok. The effect of $\mathrm{pH}$ (degree of Acidity) this is the number of ions $\mathrm{H}+$ or $\mathrm{Oh}-$ around the waters of the harbor that is worth 0.7 so affect < rate of corrosion on the steel plate material surrounding the port ships.

According to Mackereth et al., (1989), $\mathrm{pH}$ conditions closely related to carbon dioxide (CO2) and alkalinity. Alkalinity, in General, shows a concentration of alkaline or materials that can neutralize the acidity in water. The higher the $\mathrm{pH}$, the higher the value of alkalinity and the lower levels of carbon dioxide $(\mathrm{CO} 2)$ that is free. Other than alkalinity concentrations, DIC (dissolved inorganic carbon) and temperature is also an important factor in regulating the $\mathrm{pH}$ of seawater. The value of the DIC high will result in an increase of the hydrogen ions so that the $\mathrm{pH}$ of seawater (acid). The temperature will also indirectly affect the magnitude of the $\mathrm{pH}$ value, i.e. the value of big DIC when low temperatures, so a low temperature will result in the $\mathrm{pH}$ of seawater that is low in pula (Suciaty, 2011). The purpose of this study was to calculate the variation of the $\mathrm{pH}$ of the ocean waters of Indonesia in the past 18 years, knows 
the influence the condition of seasonal, annual and dynamics between the waters of according to Mackereth[6], $\mathrm{pH}$ conditions closely related to carbon dioxide

(CO2) and alkalinity. Alkalinity, in General, show a concentration of alkaline or materials that can neutralize the acidity in water. The higher the $\mathrm{pH}$, the higher the value of alkalinity and the lower levels of carbon dioxide $(\mathrm{CO} 2)$ that is free. Other than alkalinity concentrations, DIC (dissolved inorganic carbon) and temperature is also an important factor in regulating the $\mathrm{pH}$ of sea water. The value of the DIC high will result in an increase of the hydrogen ions so that the $\mathrm{pH}$ of seawater (acid). The temperature will also indirectly affect the magnitude of the $\mathrm{pH}$ value, i.e. the value of big DIC when low temperatures, so a low temperature will result in the $\mathrm{pH}$ of sea water that is low in pula (Suciaty, 2011). The purpose of this study was to calculate the variation of the $\mathrm{pH}$ of the ocean waters of Indonesia in the past 18 years, knows the influence the condition of seasonal, annual and dynamics between the waters of the According to Mackereth et al., (1989), $\mathrm{pH}$ conditions closely related to carbon dioxide (CO2) and alkalinity. Alkalinity, in General, shows a concentration of alkaline or materials that can neutralize the acidity in water. The higher the $\mathrm{pH}$, the higher the value of alkalinity and the lower levels of carbon dioxide (CO2) that is free. Other than alkalinity concentrations, DIC (dissolved inorganic carbon) and temperature is also an important factor in regulating the $\mathrm{pH}$ of sea water. The value of the DIC high will result in an increase of the hydrogen ions so that the $\mathrm{pH}$ of sea water (acid). The temperature will also indirectly affect the magnitude of the $\mathrm{pH}$ value, i.e. the value of big DIC when low temperatures, so a low temperature will result in the $\mathrm{pH}$ of seawater that is low in also. The purpose of this study was to calculate the variation of the $\mathrm{pH}$ of the ocean waters of Indonesia in the past 18 years, knows the influence the condition of seasonal, annual and dynamics between the waters of according to Mackereth et al., (1989), $\mathrm{pH}$ conditions closely related to carbon dioxide

(CO2) and alkalinity. Alkalinity, in General, shows a concentration of alkaline or materials that can neutralize the acidity in water. The higher the $\mathrm{pH}$, the higher the value of alkalinity and the lower levels of carbon dioxide (CO2) that is free. Other than alkalinity concentrations, DIC (dissolved inorganic carbon) and temperature is also an important factor in regulating the $\mathrm{pH}$ of seawater. The value of the DIC high will result in an increase of the hydrogen ions so that the $\mathrm{pH}$ of seawater (acid). The temperature will also indirectly affect the magnitude of the $\mathrm{pH}$ value, i.e. the value of big DIC when low temperatures, so a low temperature will result in the $\mathrm{pH}$ of seawater that is low in pula (Suciaty, 2011).

The purpose of this study was to calculate the $\mathrm{pH}$ variation of Indonesian waters in the

past 18 years, to determine the effect of seasonal, inter-annual conditions and waters dynamics on the $\mathrm{pH}$ of Indonesian marine waters, and to see the relationship between chemical parameters and marine physics to marine $\mathrm{pH}$ concentrations.

In general sea and coastal waters have a relatively more stable $\mathrm{pH}$ and are in a narrow range, usually ranging from 7.6 to 8.3 which means alkaline or called alkali [1] But in certain conditions, the value can change to be lower so that it becomes acidic. Such changes in $\mathrm{pH}$ values can affect the quality of the waters which in turn will have an impact on the life of the biota in it. The amount of waste originating from households, chemical industries, and fossil fuels into waters can affect the $\mathrm{pH}$ value in it. According to the quality standard KMN-KLH PP No.1 of 2010 concerning the management of water pollutants, the $\mathrm{pH}$ parameter values are included in the normal category, ranging from 6-9. 


\section{Conclusion}

This study succeeded in confirming and proving the effect of salinity and $\mathrm{pH}$ of seawater on the corrosion rate. The higher the salinity and $\mathrm{pH}$, the higher the rate of corrosion. Damage due to corrosion (rust) is a common problem that causes material degradation as interaction with its environment; so that it not only worsens its appearance but also shortens the useful life of the steel.

There are several principles of corrosion prevention that have developed; which are generally adapted to the types of equipment, places, and types of corrosive environments. Corrosion prevention in steel that is widely known is by coating steel with coatings

\section{References}

[1] M. D. Brotowidjoyo, D. Tribawono, and E. Mulbyantoro, Pengantar lingkungan perairan dan budidaya air. Yogyakarta: Liberty, 1995.

[2] A. G. Dickson and F. J. Millero, "A comparison of the equilibrium constants for the dissociation of carbonic acid in seawater media," Deep Sea Res. Part A. Oceanogr. Res. Pap., vol. 34, no. 10, pp. 1733-1743, 1987.

[3] K. R. Trethewey and J. Chamberlain, Korosi Untuk Mahasiswa Sains dan Rekayasa. Jakarta: PT. Gramedia Pustaka Utama, 1991.

[4] Y. Sofyan, Laju korosi pipa baja karbon Al06 sebagai fungsi temperature dan konsentrasi $\mathrm{NaCl}$ pada fluida yang tersaturasi CO2. Universitas Indonesia (UI), 2008.

[5] Musnasir, Laju Korosi Baja SC 42 Dalam Medium Air Laut dengan Metode Immers Total. Yogyakarta: Universitas Negeri Yogyakarta, 2009.

[6] F. J. H. Mackereth, J. Heron, and J. . Talling, Water Analysis. United Kingdom: Cumbria UK, 1989. 
